\title{
Assessment of genotoxic, cytotoxic, and protective effects of Salacia crassifolia (Mart. Ex. Schult.) G. Don. stem bark fractions in mice
}

\author{
C.C. Carneiro', C.R. Silva ${ }^{1}$, A.C.S. Menezes $^{2}$, C.N. Pérez ${ }^{3}$ and L. Chen-Chen ${ }^{1}$ \\ ${ }^{1}$ Departamento de Biologia Geral, Instituto de Ciências Biológicas, \\ Universidade Federal de Goiás, Goiânia, GO, Brasil \\ ${ }^{2}$ Instituto de Química, Universidade Estadual de Goiás, Anápolis, GO, Brasil \\ ${ }^{3}$ Instituto de Química, Universidade Federal de Goiás, Goiânia, GO, Brasil \\ Corresponding author: L. Chen-Chen \\ E-mail: chenleego@yahoo.com.br
}

Genet. Mol. Res. 12 (3): 2167-2177 (2013)

Received September 21, 2012

Accepted March 19, 2013

Published July 3, 2013

DOI http://dx.doi.org/10.4238/2013.July.3.1

\begin{abstract}
Salacia crassifolia (Mart. Ex. Schult.) G. Don., popularly known in Brazil as "bacupari", "cascudo", and "saputá", is a shrub of the Celastraceae family that is unique to the Brazilian Cerrado region. In folk medicine, this plant has been mainly used to treat skin cancer and gastric ulcers. In the present study, the genotoxic, cytotoxic, antigenotoxic, and anticytotoxic effects of $S$. crassifolia stem bark fractions (hexane, ethyl acetate, and hydroalcoholic extracts) were evaluated using the mouse bone marrow micronucleus test. Our results showed that none of the $S$. crassifolia fractions led to a significant increase in the frequency of micronucleated polychromatic erythrocytes (MNPCE) $(\mathrm{P}>0.05)$, suggesting the absence of genotoxicity. In the antigenotoxicity assessment, a significant decrease in the MNPCE frequency was observed in all fractions of this plant $(\mathrm{P}<0.05)$, demonstrating its protective action against genotoxicity induced by mitomycin C (MMC), which was used as the positive control. Only the
\end{abstract}


hexane fraction of $S$. crassifolia significantly decreased the poly- and normochromatic erythrocyte ratio $(\mathrm{PCE} / \mathrm{NCE})$ in all doses tested $(\mathrm{P}<$ 0.05), demonstrating its cytotoxic activity. In association with MMC, both ethyl acetate and hydroalcoholic fractions significantly increased the PCE/NCE ratio in almost all doses tested $(\mathrm{P}<0.05)$, demonstrating the protective action of $S$. crassifolia against the cytotoxic effect of the positive control. In contrast, the hexane fraction presented a significant decrease in the PCE/NCE ratio in all treatments $(\mathrm{P}<0.05)$, demonstrating an increase in this plant's cytotoxicity in mouse bone marrow cells.

Key words: Salacia crassifolia; Stem bark fractions; Micronucleus test; Cytotoxicity; Antigenotoxicity

\section{INTRODUCTION}

Brazil is known for its great biological and genetic diversity, with 40 to 55 thousand plant species distributed across several biomes, as well as for the great number of plants that are used by the population in folk medicine to treat a variety of diseases (de Oliveira et al., 2011).

Indeed, many plants contain good sources of compounds that are responsible for human health maintenance, reduction of oxidative damage, and protection against coronary heart diseases and cancer, including tocopherols, vitamin $\mathrm{C}$, carotenoids, and phenolic compounds (Kilani et al., 2008). However, many of these compounds can also cause harm, including DNA damage, which may lead to genetic instability and related diseases, such as cancer (Kleter et al., 2009). Therefore, it is of vital importance to evaluate the asserted pharmacological and/ or therapeutic properties of these plants, to isolate their active constituents, and to verify their possible toxicity (Marques et al., 2003).

Salacia crassifolia (Mart. Ex. Schult.) G. Don., popularly known in Brazil as "bacupari", "cascudo", and "saputá", is a shrub of the Celastraceae family that is unique to the Brazilian Cerrado region (Lombardi and Temponi, 2000). In folk medicine, the leaves, stems, seeds, and fruits of this species are used to treat pediculosis, kidney disease, gastric ulcers, skin cancer, malaria, chronic coughs, and headaches. The fruits are also used for fresh consumption and industrial purposes (Silva Júnior, 2005; Cavéchia and Proença, 2007). Previous studies have described the biological activities of this plant revealing cytotoxic, antitumoral, and antibacterial effects (Santana et al., 1971; Lima et al., 1969, 1972).

Several other studies have reported that various species of the family Celastraceae exhibit important pharmacological constituents, such as: quinone-methide triterpenes, which have antibiotic, cytotoxic, antitumor, antimalarial, and antioxidant properties (Santana et al., 1971; Lima et al., 1972; Figueiredo et al., 1998; Alvarenga et al., 1999; Jeller et al., 2004); sesquiterpenes, which show insecticide activity (Dagang et al., 1992); flavonoids, which have antioxidant properties (Corsino et al., 2003); and alkaloids, which show antitumor and insecticide activities (Corsino et al., 1998; Jinbo et al., 2002). Quinone-methide triterpenes are natural constituents whose occurrence is restricted to the family Celastraceae (Carvalho et al., 2005). Some compounds of this class have already been isolated from $S$. crassifolia, such as maytenin and pristimerin, which have been proven to present not only significant cytotoxic 
and antimicrobial activities, but also potent antitumor activity (Santana et al., 1971; Lima et al., 1969, 1972). It is also believed that these molecules are potential antineoplastic agents (Buffa Filho et al., 2004; Lu et al., 2010; Yadav et al., 2010).

Although studies involving species of the family Celastraceae are prominent, only a few have focused on S. crassifolia specifically. Caramori et al. (2004) demonstrated that $S$. crassifolia seed extracts contain a considerable amount of polyphenols and tannins, as well as compounds with nutritional value, such as proteins, carbohydrates, and lipids.

Therefore, further studies with S. crassifolia are needed in order to prove its effectiveness in treating a variety of diseases and to know the risks associated with its intake, as well as the pharmacological effects of its active constituents.

Due to the large utilization of S. crassifolia and the relevant pharmacological constituents present in this plant, the present study aimed to evaluate the genotoxic, cytotoxic, antigenotoxic, and anticytotoxic effects of the stem bark fractions [hexane (HEF), ethyl acetate (EAF), and hydroalcoholic extracts (HAF)] of this species using the mouse bone marrow micronucleus test.

\section{MATERIAL AND METHODS}

\section{Plant material}

Samples of $S$. crassifolia stem bark were collected in Anápolis, GO, Brazil $\left(16^{\circ} 12^{\prime} 49^{\prime \prime} \mathrm{S}\right.$, $\left.48^{\circ} 57^{\prime} 57^{\prime \prime} \mathrm{W}\right)$. The plant was identified by Dr. Mirley Luciene dos Santos and a voucher specimen (No. 5910) was deposited in the Central Herbarium of Universidade Estadual de Goiás, in Anápolis.

The stem bark samples were dried in a forced-air oven at $45^{\circ} \mathrm{C}$ and ground in a fraction mill to obtain a dry powder that was then subjected to extraction with methanol in an exhaustive manner. The organic solvent was evaporated at reduced pressure with a rotary evaporator to a residue we named crude methanolic extract. The crude methanolic extract was resuspended in 1:3 methanol:water and partitioned according to the polarity of the solvents hexane, dichloromethane, and ethyl acetate. The following fractions of S. crassifolia stem bark were obtained: HEF, dichloromethane, EAF, and HAF. Dichloromethane was excluded from this study, because its mass was insufficient to perform the experiments. HEF, EAF, and HAF were stocked at $5^{\circ} \mathrm{C}$ until use, at which point they were dissolved in dimethylsulfoxide (DMSO).

\section{Chemical agents}

The following chemicals were used in the experiments: mitomycin $\mathrm{C}$ (MMC, $\mathrm{C}_{15} \mathrm{H}_{18} \mathrm{~N}_{4} \mathrm{O}_{5}$; Bristol-Myers Squibb, No. 237AEL), dibasic sodium phosphate $\left(\mathrm{Na}_{2} \mathrm{HPO}_{4} 12 \mathrm{H}_{2} \mathrm{O}\right.$; Vetec, No. 982162), monobasic sodium phosphate $\left(\mathrm{NaH}_{2} \mathrm{PO}_{4} \mathrm{H}_{2} \mathrm{O}\right.$; Vetec, No. 983831), methanol $\left(\mathrm{CH}_{4} \mathrm{O}\right.$; Synth, No. 55026), Giemsa (Doles, No. 1081), and fetal calf serum (FCS; Laborclin, No. 30721063).

\section{Animals}

This study was approved by the Research Ethics Committee of Universidade Federal 
de Goiás (CoEP-UFG, No. 225/11). Healthy, young male adult (8-12 weeks) outbred mice (Mus musculus, Swiss Webster), weighing 25-30 g, obtained from the Central Animal House of UFG, were used in this study. All animals were brought to the laboratory 5 days before the experiments and housed in plastic cages $(40 \times 30 \times 16 \mathrm{~cm})$ at $24^{\circ} \pm 2^{\circ} \mathrm{C}$ and $55 \pm 10 \%$ relative humidity, with a light-dark natural cycle of $12 \mathrm{~h}$. The animals were fed appropriate commercial rodent diet (Labina, Ecibra Ltda., Santo Amaro, SP, Brazil) and water ad libitum.

\section{Experimental procedure}

The experiments were performed according to methods described in von Ledebur and Schmid (1973). For each treatment, groups of 5 animals were treated orally with 50, 100, or $150 \mathrm{mg} / \mathrm{kg}$ HEF, EAF, or HAF, according to body weight, for the evaluation of $S$. crassifolia genotoxicity. The same doses of the three fractions were co-treated with MMC for the evaluation of this species' antigenotoxicity. A positive control group (MMC, $4 \mathrm{mg} / \mathrm{kg}$ intraperitoneally), a negative control group (sterile distilled water) and a solvent control group (DMSO, $0.1 \mathrm{~mL} / 10 \mathrm{~g}$ body weight) were also included. The animals were euthanized 24 or $48 \mathrm{~h}$ after the administration of HEF, EAF, or HAF by cervical dislocation, and their bone marrow cells were flushed from both femurs in fetal calf serum. After centrifugation $(300 \mathrm{~g}, 5 \mathrm{~min})$, the bone marrow cells were smeared on glass slides, coded for blind analysis, air-dried, and fixed with absolute methanol for $5 \mathrm{~min}$ at room temperature. The smears were stained with Giemsa, dibasic sodium phosphate, and monobasic sodium phosphate. For each animal, we prepared three slides and counted 2000 polychromatic erythrocytes (PCE) to determine the frequency of micronucleated polychromatic erythrocytes (MNPCE). Genotoxicity and antigenotoxicity were assessed by the frequency of MNPCE, whereas cytotoxicity and anticytotoxicity were evaluated by the ratio of PCE to normochromatic erythrocytes (NCE). The slides were analyzed using a microscope (Olympus BH-2 10x100, Tokyo, Japan).

\section{Statistical analysis}

To analyze S. crassifolia genotoxic activity, we compared the frequency of MNPCE detected in the treated groups with that of the solvent control group using one-way analysis of variance (ANOVA). To assess the antigenotoxic activity of $S$. crassifolia, the frequency of MNPCE in the treated groups was compared with the positive control group (ANOVA). The Tukey test was applied for a multiple comparison after ANOVA, and P values lower than 0.05 $(\mathrm{P}<0.05)$ were considered to be indicative of significance. To evaluate the cytotoxicity of $S$. crassifolia, the PCE/NCE ratio of all treated groups was compared with the solvent control group using the chi-squared test $\left(\chi^{2}\right)$. To evaluate $S$. crassifolia anticytotoxicity, the PCE/NCE ratio of all treated groups was compared with the positive control group using the $\chi^{2}$ test. $\mathrm{P}$ values lower than $0.05(\mathrm{P}<0.05)$ were considered to be indicative of significance.

\section{RESULTS}

The results of HEF, EAF, and HAF genotoxicity, cytotoxicity, antigenotoxicity, and anticytotoxicity are shown in Tables 1,2 , and 3, respectively.

In this study, the negative control and the solvent control groups demonstrated low 
MNPCE values, as expected, and the positive control group's MNPCE frequency was significantly higher $(\mathrm{P}<0.05)$, confirming the sensitivity of the test.

The HEF genotoxicity analysis, for all doses tested $(50,100$, and $150 \mathrm{mg} / \mathrm{kg})$, indicated no significant increase in the MNPCE frequency at 24 and $48 \mathrm{~h}$ when compared with the solvent control group $(\mathrm{P}>0.05)$, leading to the conclusion that the HEF of $S$. crassifolia stem bark does not have genotoxic effects (Table 1).

\begin{tabular}{|c|c|c|c|c|}
\hline Sampling time/treatment & Individual data (MNPCE/2000 PCE) & Total MNPCE & Means \pm SD (MNPCE) & Means $\pm \mathrm{SD}(\mathrm{PCE} / \mathrm{NCE})$ \\
\hline \multicolumn{5}{|l|}{$24 \mathrm{~h}$} \\
\hline Water $^{1}$ & $3,5,3,4,4$ & 19 & $3.8 \pm 0.74^{\mathrm{c}}$ & $1.06 \pm 0.06^{\mathrm{c}}$ \\
\hline $\mathrm{DMSO}^{2}$ & $4,4,4,4,5$ & 21 & $4.2 \pm 0.4^{c}$ & $1.1 \pm 0.05^{\mathrm{c}}$ \\
\hline $\mathrm{MMC}^{3}$ & $34,32,33,30,34$ & 163 & $32.6 \pm 1.67^{\mathrm{a}}$ & $0.7 \pm 0.01^{\mathrm{a}}$ \\
\hline \multicolumn{5}{|l|}{ HEF alone } \\
\hline $50 \mathrm{mg} / \mathrm{kg}$ & $3,4,3,3,4$ & 17 & $3.4 \pm 0.49^{\mathrm{b}}$ & $0.94 \pm 0.02^{\mathrm{a}}$ \\
\hline $100 \mathrm{mg} / \mathrm{kg}$ & $2,2,2,2,3$ & 11 & $2.2 \pm 0.4^{\mathrm{b}}$ & $0.81 \pm 0.05^{\mathrm{a}}$ \\
\hline $150 \mathrm{mg} / \mathrm{kg}$ & $3,2,2,3,1$ & 11 & $2.2 \pm 0.75^{\mathrm{b}}$ & $0.87 \pm 0.05^{\mathrm{a}}$ \\
\hline \multicolumn{5}{|l|}{$\mathrm{HEF}+\mathrm{MMC}$} \\
\hline $50 \mathrm{mg} / \mathrm{kg}$ & $9,9,11,13,9$ & 51 & $10.2 \pm 1.78^{\mathrm{c}}$ & $0.58 \pm 0.05^{\mathrm{c}}$ \\
\hline $100 \mathrm{mg} / \mathrm{kg}$ & $8,9,5,9,4$ & 35 & $7.0 \pm 2.09^{c}$ & $0.59 \pm 0.05^{\mathrm{c}}$ \\
\hline $150 \mathrm{mg} / \mathrm{kg}$ & $4,4,5,4,4$ & 21 & $4.2 \pm 0.4^{\mathrm{c}}$ & $0.62 \pm 0.06^{\mathrm{c}}$ \\
\hline \multicolumn{5}{|l|}{$48 \mathrm{~h}$} \\
\hline DMSO & $4,3,3,3,4$ & 17 & $3.4 \pm 0.49^{c}$ & $1.09 \pm 0.09^{c}$ \\
\hline MMC & $10,12,11,12,14$ & 59 & $11.8 \pm 1.48^{\mathrm{a}}$ & $0.55 \pm 0.01^{\mathrm{a}}$ \\
\hline \multicolumn{5}{|l|}{ HEF alone } \\
\hline $50 \mathrm{mg} / \mathrm{kg}$ & $3,2,3,3,3$ & 14 & $2.8 \pm 0.4^{\mathrm{b}}$ & $0.98 \pm 0.16^{\mathrm{a}}$ \\
\hline $100 \mathrm{mg} / \mathrm{kg}$ & $2,1,2,2,3$ & 10 & $2.0 \pm 0.63^{b}$ & $0.86 \pm 0.08^{\mathrm{a}}$ \\
\hline $150 \mathrm{mg} / \mathrm{kg}$ & $3,2,1,2,3$ & 11 & $2.2 \pm 0.75^{\mathrm{b}}$ & $0.82 \pm 0.05^{\mathrm{a}}$ \\
\hline \multicolumn{5}{|l|}{$\mathrm{HEF}+\mathrm{MMC}$} \\
\hline $50 \mathrm{mg} / \mathrm{kg}$ & $6,6,5,5,4$ & 26 & $5.2 \pm 0.83^{\mathrm{c}}$ & $0.5 \pm 0.06^{\mathrm{c}}$ \\
\hline $100 \mathrm{mg} / \mathrm{kg}$ & $3,3,4,3,3$ & 16 & $3.2 \pm 0.4^{c}$ & $0.32 \pm 0.02^{\mathrm{c}}$ \\
\hline $150 \mathrm{mg} / \mathrm{kg}$ & $2,2,2,3,4$ & 13 & $2.6 \pm 0.8^{c}$ & $0.36 \pm 0.05^{\mathrm{c}}$ \\
\hline
\end{tabular}

All results were compared with the respective control group at the respective time. ${ }^{1}$ Negative control $=$ distilled

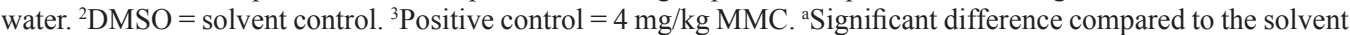
control group $(\mathrm{P}<0.05)$. ${ }^{\mathrm{b}}$ No significant difference compared to the solvent control group $(\mathrm{P}>0.05)$. ${ }^{\mathrm{c}}$ Significant difference compared to the positive control group $(\mathrm{P}<0.05)$. ${ }^{\mathrm{d}}$ No significant difference compared to the positive control group $(\mathrm{P}>0.05)$.

Regarding HEF cytotoxicity, all doses tested $(50,100$, and $150 \mathrm{mg} / \mathrm{kg}$ ) at both treatment times ( 24 and $48 \mathrm{~h}$ ) caused a significant reduction in the PCE/NCE ratio relative to the solvent control group $(\mathrm{P}<0.05)$, although this reduction was relatively small at the $50 \mathrm{mg} / \mathrm{kg}$ dose level (Table 1).

In the HEF antigenotoxic evaluation, for all doses tested $(50,100$, and $150 \mathrm{mg} / \mathrm{kg}$ $\mathrm{HEF}+\mathrm{MMC}$ ), the mean MNPCE values (per $2000 \mathrm{PCE}$ ) were 10.2, 7.0, and 4.2 at $24 \mathrm{~h}$, and $5.2,3.2$, and 2.6 at $48 \mathrm{~h}$, respectively, whereas for the positive control group, they were 32.6 at $24 \mathrm{~h}$ and 11.8 at $48 \mathrm{~h}$ (Table 1). These results show that HEF strongly modulated the genotoxic activity of MMC at both treatment times $(\mathrm{P}<0.05)$, demonstrating its antigenotoxic effect.

With respect to HEF anticytotoxicity, the observed that PCE/NCE ratios were 0.58 , 0.59 , and 0.62 at $24 \mathrm{~h}$ and $0.5,0.32$, and 0.36 at $48 \mathrm{~h}$ in treatments with doses of 50, 100, and $150 \mathrm{mg} / \mathrm{kg} \mathrm{HEF}+\mathrm{MMC}$, respectively, whereas for the positive control group, they were 0.7 
at $24 \mathrm{~h}$ and 0.55 at $48 \mathrm{~h}$ (Table 1). The statistical analysis showed that all doses of HEF at both times of treatment caused significant reductions in the PCE/NCE ratio compared with those of the positive control group $(\mathrm{P}<0.05)$. Therefore, we observed that the HEF of $S$. crassifolia stem bark significantly increased the cytotoxicity induced by MMC.

The EAF genotoxic activity assessment showed that none of the doses tested $(50,100$, and $150 \mathrm{mg} / \mathrm{kg}$ ) caused significant increases in the MNPCE frequency at 24 or $48 \mathrm{~h}$ when compared with that of the solvent control group $(\mathrm{P}>0.05)$, indicating no genotoxic effect under these experimental conditions (Table 2).

\begin{tabular}{|c|c|c|c|c|}
\hline Sampling time/treatment & Individual data (MNPCE/2000 PCE) & Total MNPCE & Means $\pm \mathrm{SD}$ (MNPCE) & Means $\pm \mathrm{SD}(\mathrm{PCE} / \mathrm{NCE})$ \\
\hline \multicolumn{5}{|l|}{$24 \mathrm{~h}$} \\
\hline Water $^{1}$ & $3,5,3,4,4$ & 19 & $3.8 \pm 0.74^{\mathrm{c}}$ & $1.06 \pm 0.06^{\mathrm{c}}$ \\
\hline $\mathrm{DMSO}^{2}$ & $4,4,4,4,5$ & 21 & $4.2 \pm 0.4^{c}$ & $1.1 \pm 0.05^{\mathrm{c}}$ \\
\hline $\mathrm{MMC}^{3}$ & $34,32,33,30,34$ & 163 & $32.6 \pm 1.67^{\mathrm{a}}$ & $0.7 \pm 0.01^{\mathrm{a}}$ \\
\hline \multicolumn{5}{|l|}{ EAF alone } \\
\hline $50 \mathrm{mg} / \mathrm{kg}$ & $3,4,2,3,3$ & 15 & $3.0 \pm 0.63^{\mathrm{b}}$ & $1.09 \pm 0.04^{\mathrm{b}}$ \\
\hline $100 \mathrm{mg} / \mathrm{kg}$ & $3,3,3,4,3$ & 16 & $3.2 \pm 0.4^{\mathrm{b}}$ & $1.14 \pm 0.07^{\mathrm{b}}$ \\
\hline 150 mg.kg & $3,2,2,2,3$ & 12 & $2.4 \pm 0.49^{\mathrm{b}}$ & $1.05 \pm 0.05^{\mathrm{b}}$ \\
\hline \multicolumn{5}{|l|}{$\mathrm{EAF}+\mathrm{MMC}$} \\
\hline $50 \mathrm{mg} / \mathrm{kg}$ & $16,20,19,21,22$ & 98 & $19.6 \pm 2.3^{c}$ & $0.82 \pm 0.04^{c}$ \\
\hline $100 \mathrm{mg} / \mathrm{kg}$ & $15,14,12,09,13$ & 63 & $12.6 \pm 2.3^{\mathrm{c}}$ & $0.76 \pm 0.04^{c}$ \\
\hline $150 \mathrm{mg} / \mathrm{kg}$ & $11,08,13,13,11$ & 56 & $11.2 \pm 2.04^{\mathrm{c}}$ & $0.78 \pm 0.01^{\mathrm{c}}$ \\
\hline \multicolumn{5}{|l|}{$48 \mathrm{~h}$} \\
\hline DMSO & $4,3,3,3,4$ & 17 & $3.4 \pm 0.49^{\mathrm{c}}$ & $1.09 \pm 0.09^{c}$ \\
\hline MMC & $10,12,11,12,14$ & 59 & $11.8 \pm 1.48^{\mathrm{a}}$ & $0.55 \pm 0.01^{\mathrm{a}}$ \\
\hline \multicolumn{5}{|l|}{ EAF alone } \\
\hline $50 \mathrm{mg} / \mathrm{kg}$ & $5,3,4,4,4$ & 20 & $4.0 \pm 0.63^{\mathrm{b}}$ & $1.08 \pm 0.03^{\mathrm{b}}$ \\
\hline $100 \mathrm{mg} / \mathrm{kg}$ & $2,2,3,2,2$ & 11 & $2.2 \pm 0.4^{\mathrm{b}}$ & $1.12 \pm 0.05^{\mathrm{b}}$ \\
\hline $150 \mathrm{mg} / \mathrm{kg}$ & $3,3,3,2,3$ & 14 & $2.8 \pm 0.4^{\mathrm{b}}$ & $1.08 \pm 0.02^{\mathrm{b}}$ \\
\hline \multicolumn{5}{|l|}{$\mathrm{EAF}+\mathrm{MMC}$} \\
\hline $50 \mathrm{mg} / \mathrm{kg}$ & $9,9,12,9,8$ & 47 & $9.4 \pm 1.35^{\mathrm{c}}$ & $0.67 \pm 0.007^{\circ}$ \\
\hline $100 \mathrm{mg} / \mathrm{kg}$ & $9,7,10,9,8$ & 43 & $8.6 \pm 1.02^{\mathrm{c}}$ & $0.65 \pm 0.01^{\mathrm{c}}$ \\
\hline $150 \mathrm{mg} / \mathrm{kg}$ & $7,8,9,8,5$ & 37 & $7.4 \pm 1.35^{\mathrm{c}}$ & $0.68 \pm 0.05^{\mathrm{c}}$ \\
\hline
\end{tabular}

All results were compared with the respective control group at the respective time. ${ }^{1}$ Negative control $=$ distilled

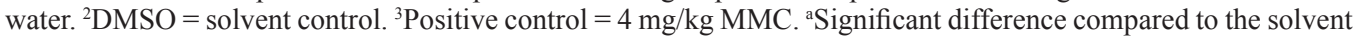

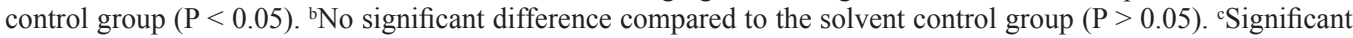
difference compared to the positive control group $(\mathrm{P}<0.05)$. ${ }^{\mathrm{d}}$ No significant difference compared to the positive control group $(\mathrm{P}>0.05)$.

With respect to EAF cytotoxicity, no significant differences were observed between each of the PCE/NCE ratios for all doses tested $(50,100$, and $150 \mathrm{mg} / \mathrm{kg})$ and the respective doses of the solvent control groups at either time of treatment $(\mathrm{P}>0.05)$ (Table 2). Thus, the EAF of $S$. crassifolia stem bark did not exhibit genotoxic or cytotoxic activities under our experimental conditions.

According to our results, the mean MNPCE values (per 2000 EPC) of the groups treated with 50,100, and $150 \mathrm{mg} / \mathrm{kg}$ EAF + MMC were 19.6, 12.6, and 11.2 at $24 \mathrm{~h}$, and 9.4, 8.6, and 7.4 at $48 \mathrm{~h}$, respectively, whereas in the positive control group, they were 32.6 at $24 \mathrm{~h}$ and 11.8 at $48 \mathrm{~h}$ (Table 2). These results show that the EAF of $S$. crassifolia stem bark protected the mouse cells against MMC genotoxicity $(\mathrm{P}<0.05)$ in all doses tested at both treatment times, demonstrating its strong antigenotoxic effect. 
In the anticytotoxic evaluation, the PCE/NCE ratios of the groups treated with 50, 100 , and $150 \mathrm{mg} / \mathrm{kg}$ EAF + MMC were 0.82, 0.76 , and 0.78 at $24 \mathrm{~h}$, and $0.67,0.65$, and 0.68 at $48 \mathrm{~h}$, respectively, and in the positive control group they were 0.7 at $24 \mathrm{~h}$ and 0.55 at $48 \mathrm{~h}$, demonstrating a moderate anticytotoxic effect of EAF at all doses tested $(\mathrm{P}<0.05)$ (Table 2).

No significant differences in the MNPCE frequency were observed during the genotoxic evaluation of HAF when compared with that of the solvent control group at 24 and $48 \mathrm{~h}$ at any of the doses tested $(\mathrm{P}>0.05)$, suggesting a lack of genotoxicity of this fraction (Table 3 ).

No significant differences were observed in the PCE/NCE ratios of HAF compared with those of the solvent control group at any dose tested $(50,100$, and $150 \mathrm{mg} / \mathrm{kg}$ ), or at either treatment time $(\mathrm{P}>0.05)$, indicating that this fraction presented no cytotoxic effects.

\begin{tabular}{|c|c|c|c|c|}
\hline Sampling time/treatment & Individual data (MNPCE/2000 PCE) & Total MNPCE & Means \pm SD (MNPCE) & Means $\pm \mathrm{SD}(\mathrm{PCE} / \mathrm{NCE})$ \\
\hline \multicolumn{5}{|l|}{$24 \mathrm{~h}$} \\
\hline Water $^{1}$ & $3,5,3,4,4$ & 19 & $3.8 \pm 0.74^{\mathrm{c}}$ & $1.06 \pm 0.06^{\mathrm{c}}$ \\
\hline $\mathrm{DMSO}^{2}$ & $4,4,4,4,5$ & 21 & $4.2 \pm 0.4^{c}$ & $1.1 \pm 0.05^{\mathrm{c}}$ \\
\hline $\mathrm{MMC}^{3}$ & $34,32,33,30,34$ & 163 & $32.6 \pm 1.67^{\mathrm{a}}$ & $0.7 \pm 0.01^{\mathrm{a}}$ \\
\hline \multicolumn{5}{|l|}{ HAF alone } \\
\hline $50 \mathrm{mg} / \mathrm{kg}$ & $3,3,4,4,4$ & 18 & $3.6 \pm 0.49^{b}$ & $1.08 \pm 0.04^{b}$ \\
\hline $100 \mathrm{mg} / \mathrm{kg}$ & $2,3,4,3,4$ & 16 & $3.2 \pm 0.75^{\mathrm{b}}$ & $1.01 \pm 0.02^{\mathrm{b}}$ \\
\hline $150 \mathrm{mg} / \mathrm{kg}$ & $2,2,2,3,2$ & 11 & $2.2 \pm 0.4^{b}$ & $1.05 \pm 0.03^{b}$ \\
\hline \multicolumn{5}{|l|}{$\mathrm{HAF}+\mathrm{MMC}$} \\
\hline $50 \mathrm{mg} / \mathrm{kg}$ & $20,22,18,17,23$ & 100 & $20.0 \pm 2.28^{\mathrm{c}}$ & $0.72 \pm 0.05^{\mathrm{d}}$ \\
\hline $100 \mathrm{mg} / \mathrm{kg}$ & $16,15,13,15,16$ & 75 & $15.0 \pm 1.09^{\mathrm{c}}$ & $0.78 \pm 0.02^{\mathrm{c}}$ \\
\hline $150 \mathrm{mg} / \mathrm{kg}$ & $11,10,10,10,13$ & 54 & $10.8 \pm 1.16^{\mathrm{c}}$ & $0.82 \pm 0.04^{c}$ \\
\hline \multicolumn{5}{|l|}{$48 \mathrm{~h}$} \\
\hline DMSO & $4,3,3,3,4$ & 17 & $3.4 \pm 0.49^{\circ}$ & $1.09 \pm 0.09^{\mathrm{c}}$ \\
\hline MMC & $10,12,11,12,14$ & 59 & $11.8 \pm 1.48^{\mathrm{a}}$ & $0.55 \pm 0.01^{\mathrm{a}}$ \\
\hline \multicolumn{5}{|l|}{ HAF alone } \\
\hline $50 \mathrm{mg} / \mathrm{kg}$ & $2,4,4,3,3$ & 16 & $3.2 \pm 0.74^{\mathrm{b}}$ & $1.05 \pm 0.04^{b}$ \\
\hline $100 \mathrm{mg} / \mathrm{kg}$ & $4,4,3,4,3$ & 18 & $3.6 \pm 0.49^{\mathrm{b}}$ & $1.07 \pm 0.04^{b}$ \\
\hline $150 \mathrm{mg} / \mathrm{kg}$ & $3,2,3,3,4$ & 15 & $3.0 \pm 0.63^{b}$ & $1.05 \pm 0.04^{b}$ \\
\hline \multicolumn{5}{|l|}{$\mathrm{HAF}+\mathrm{MMC}$} \\
\hline $50 \mathrm{mg} / \mathrm{kg}$ & $10,9,8,8,9$ & 44 & $8.8 \pm 0.75^{\mathrm{c}}$ & $0.58 \pm 0.05^{\mathrm{d}}$ \\
\hline $100 \mathrm{mg} / \mathrm{kg}$ & $11,7,7,8,8$ & 41 & $8.2 \pm 1.47^{\circ}$ & $0.6 \pm 0.02^{\mathrm{c}}$ \\
\hline $150 \mathrm{mg} / \mathrm{kg}$ & $10,6,7,8,7$ & 38 & $7.6 \pm 1.35^{\mathrm{c}}$ & $0.65 \pm 0.03^{\mathrm{c}}$ \\
\hline
\end{tabular}

All results were compared with the respective control group at the respective time. ${ }^{1}$ Negative control $=$ distilled water. ${ }^{2} \mathrm{DMSO}=$ solvent control. ${ }^{3} \mathrm{Positive}$ control $=4 \mathrm{mg} / \mathrm{kg} \mathrm{MMC}$. a Significant difference compared to the solvent control group $(\mathrm{P}<0.05)$. ${ }^{\mathrm{b}}$ No significant difference compared to the solvent control group $(\mathrm{P}>0.05)$. ${ }^{\mathrm{c}}$ Significant difference compared to the positive control group $(\mathrm{P}<0.05)$. ${ }^{\mathrm{d}}$ No significant difference compared to the positive control group $(\mathrm{P}>0.05)$.

Regarding the HAF antigenotoxicity, our results showed that the mean MNPCE values (per 2000 EPC) of the groups treated with 50,100 , and $150 \mathrm{mg} / \mathrm{kg} \mathrm{HAF}+\mathrm{MMC}$ were $20.0,15.0$, and 10.8 at $24 \mathrm{~h}$, and $8.8,8.2$, and 7.6 at $48 \mathrm{~h}$, respectively, whereas for the positive control group, they were 32.6 at $24 \mathrm{~h}$ and 11.8 at $48 \mathrm{~h}$ (Table 3). According to these results, the HAF modulated the genotoxic activity of MMC at both treatment times, demonstrating its antigenotoxic effect $(\mathrm{P}<0.05)$.

In the evaluation of $\mathrm{HAF}$ anticytotoxicity, the $\mathrm{PCE} / \mathrm{NCE}$ ratios obtained at doses of 50,100 , and $150 \mathrm{mg} / \mathrm{kg} \mathrm{HAF}+\mathrm{MMC}$ were $0.72,0.78$, and 0.82 at $24 \mathrm{~h}$ and $0.58,0.6$ and 0.65 at $48 \mathrm{~h}$, respectively, whereas for the positive control group, they were 0.7 at $24 \mathrm{~h}$ and 0.55 at 
$48 \mathrm{~h}$ (Table 3). These results demonstrated a significant increase in the PCE/NCE ratio compared to that of the respective positive control group $(\mathrm{P}<0.05)$ at doses of 100 and $150 \mathrm{mg} /$ $\mathrm{kg} \mathrm{HAF}$ co-administered with MMC, demonstrating a significant decrease in the cytotoxicity induced by MMC.

\section{DISCUSSION}

Although $S$. crassifolia has been broadly used in folk medicine to treat a variety of diseases, it remains unknown if this plant actually poses any risks to people and/or protect them against the genotoxic action of some compounds. Therefore, the aim of this study was to evaluate the genotoxic, cytotoxic, antigenotoxic, and anticytotoxic effects of the HEF, EAF, and HAF of $S$. crassifolia stem bark using the mouse bone marrow micronucleus test.

The mouse bone marrow micronucleus test is a short-term assay that is widely employed to detect genetic alterations arising from chromosomal damage and/or damage to the mitotic apparatus caused by clastogenic or aneugenic agents. As micronuclei are indicative of irreversible DNA loss, their frequency may be used as a mutation index. Moreover, positive correlations between increased micronucleus frequency and the occurrence of tumors in rodents and humans have been widely observed (Hayashi et al., 2000).

The results of the genotoxic assessment of $S$. crassifolia showed that for all doses tested $(50,100$, and $150 \mathrm{mg} / \mathrm{kg}$ ) and treatment times ( 24 and $48 \mathrm{~h})$, neither the HEF, EAF, or HAF resulted in significant increases in the MNPCE frequency relative to the solvent control group $(\mathrm{P}>0.05)$ and, therefore, did not exhibit genotoxic activity in PCE in mouse bone marrow cells.

To the best of our knowledge, so far, no studies have demonstrated genotoxic effects of $S$. crassifolia. However, studies with other species of the same genus have revealed such effects. Flammang et al. $(2006,2007)$ demonstrated that the root extract of $S$. oblonga did not present mutagenicity using the Ames test in strains of Salmonella typhimurium and a test of chromosomal aberrations in cultured rat peripheral blood lymphocytes (in vivo study). Previous studies have demonstrated that various extracts of Salacia species (S. oblonga, $S$. chinensis, and $S$. prioidis) show potent $\alpha$-glucosidase-inhibitory activity, which may be used as adjunctive therapy in the treatment of individuals with diabetes mellitus (Matsuda et al., 2002; Muraoka et al., 2010).

Mangiferin is an active constituent of these species, and demonstrates antidiabetic properties based on observed decreases of insulin resistance in non-insulin-dependent mice (Miura et al., 2001). As a result, mangiferin isolated from $S$. chinensis was evaluated in a series of genotoxicity studies to confirm the safety of its usage, and showed no mutagenicity up to 5 $\mathrm{mg} / \mathrm{plate}$ when tested in S. typhimurium strains TA 97a, TA 98, TA 100, TA 102, and TA 1535, both with and without metabolic activation (Govindaraj et al., 2009). Therefore, our results are in agreement with the findings of Flammang et al. (2006, 2007) and Govindaraj et al. (2009).

The micronucleus test used in our study also detects cytotoxic effects, based on the $\mathrm{PCE} / \mathrm{NCE}$ ratio. When the proliferation of bone marrow cells is affected by a toxic agent, the number of immature erythrocytes (PCE) decreases in relation to that of mature erythrocytes (NCE), leading to a decrease in the PCE/NCE ratio (Hayashi et al., 2000). Our results showed that neither the EAF nor the HAF exhibited cytotoxic activity at any dose and time analyzed, whereas the HEF exhibited mild cytotoxic activity at the lowest dose $(50 \mathrm{mg} / \mathrm{kg})$ and moderate toxic effects at doses of 100 and $150 \mathrm{mg} / \mathrm{kg}$ at both time periods. 
Previous studies conducted with species of the family Celastraceae have shown important cytotoxic activity related to some of their isolated constituents. Pristimerin, a very common quinone-methide triterpene in Celastraceae species, has been isolated from Maytenus catigarum root bark hexane fractions (Alvarenga et al., 1999), S. beddomei stem bark slightly polar fractions (Hisham et al., 1995), and S. crassifolia root bark hexane fractions (Lima et al., 1972). The cytotoxic activity of this compound has proven to be effective against certain bacteria, fungi, and tumor cells in several studies (González et al., 1998; Alvarenga et al., 1999; Gullo et al., 2012). Therefore, we believe that the HEF of $S$. crassifolia stem bark may contain chemical substances, such as pristimerin, that have a cytotoxic profile.

The chemotherapeutic agent MMC was used in the assessment of S. crassifolia antigenotoxic and anticytotoxic effects in our study. The action of this compound can occur due to different mechanisms: alkylation of DNA, generation of free radicals, such as superoxides, and generation of hydroxyl radicals, which induce breaks and other lesions in DNA strands (Kumar et al., 1992). The lesions generated by MMC can also cause the blockage of DNA replication, resulting in the cytotoxic action of this compound.

In the antigenotoxic evaluation of $S$. crassifolia extract fractions, our results indicated that all doses tested $(50,100$, and $150 \mathrm{mg} / \mathrm{kg}$ ), at both 24 and $48 \mathrm{~h}$, protected the mouse bone marrow cells against the genotoxic activity of MMC, suggesting the presence of antigenotoxic compounds in all three fractions of this plant.

Phytochemical studies with several species of the genus Salacia have demonstrated the presence of phenolic compounds, quinone-methide triterpenes, friedelane triterpenes, and flavonoids, which show antioxidant and free radical scavenging activities (Morikawa et al., 2003; Carvalho et al., 2005; Muraoka et al., 2010; Somwong et al., 2011). Caramori et al. (2004) demonstrated that the seed extract of S. crassifolia contains a considerable amount of polyphenols. Phenolic compounds derived from secondary metabolism of plants are important natural antioxidants (Atoui et al., 2005).

In general, terpenes with antioxidant properties are rare, but some examples are common in species of the family Celastraceae, such as rosmanol, celastrol, maytenin, and pristimerin (Corsino et al., 2000; Carvalho et al., 2005). Among these compounds, two quinonemethide triterpenes have already been isolated from $S$. crassifolia: pristimerin and maytenin (Lima et al., 1969; Santana et al., 1971; Carvalho et al., 2005). Therefore, S. crassifolia antigenotoxicity may be attributed, at least partially, to the action of phenolic compounds and quinone-methide triterpenes present in this species.

Regarding S. crassifolia anticytotoxicity, in our study, EAF and HAF protected the mouse bone marrow cells against the cytotoxic effects of MMC, while the HEF significantly increased the cytotoxicity induced by MMC at all doses and times analyzed. A compound that inhibits MMC genotoxicity can also inhibit its cytotoxicity and prevent irreparable damage to DNA that would lead to cell death. On the other hand, it has previously been demonstrated that the association of MMC with other antitumor agents may cause an increase in their cytotoxic effects due to an increase in apoptosis induction (Kraut and Drnovsek-Olup, 1996). This fact was also observed in our study using the HEF of $S$. crassifolia, suggesting a synergistic action of this fraction with the positive control.

Studies carried out with triterpenes isolated from Maytenus diversifolia (Celastraceae) showed significant antileukemic activity and high cytotoxicity against A-549 lung carcinoma cells (Nozaki et al., 1990). Other studies with species of the same family showed that sesquiterpene pyridine alkaloids from M. aquifolium, quinone-methide triterpenes from S. liana, and 
phenolic triterpenes from Cheiloclinium cognatum are all promising secondary metabolites for the therapy and chemoprevention of cancer, particularly because they exhibit potent cytotoxic and antioxidant activities (Corsino et al., 1998; Jeller et al., 2004).

In summary, our results indicated that none of the fractions tested of S. crassifolia stem bark exhibited genotoxic effects in mice, but did demonstrate strong antigenotoxic effects, suggesting the presence of phenolic compounds and quinone-methide triterpenes. Furthermore, the cytotoxicity of $S$. crassifolia was only evident in HEF. In association with MMC, EAF and HAF protected the mouse bone marrow cells against the cytotoxic effect of this positive control, whereas the HEF increased the cytotoxicity induced by MMC, suggesting a synergistic action of this fraction with the positive control. Therefore, the antigenotoxicity demonstrated by $S$. crassifolia, as well as the increased cytotoxic action of HEF when co-administered with $\mathrm{MMC}$, may provide important information for future developments of novel cancer therapies.

\section{ACKNOWLEDGMENTS}

We are grateful to all sponsors of this study: Fundação de Amparo à Pesquisa do Estado de Goiás (FAPEG), Fundação de Apoio à Pesquisa (FUNAP), Coordenação de Aperfeiçoamento de Pessoal de Nível Superior (CAPES), and Universidade Federal de Goiás (UFG).

\section{REFERENCES}

Alvarenga NL, Velázquez CA, Gomez R, Canela NJ, et al. (1999). A new antibiotic nortriterpene quinone methide from Maytenus catingarum. J. Nat. Prod. 62: 750-751.

Atoui AK, Mansouri A, Boskou G and Kefalas P (2005). Teas and herbal infusions: their antioxidant activity and phenolic profile. Food Chem. 89: 27-36.

Buffa Filho W, Bolzani VS, Furlan M, Pereira SIV, et al. (2004). In vitro propagation of Maytenus ilicifolia (Celastraceae) as potential source for antitumoral and antioxidant quinonemethide triterpenes production. A rapid quantitative method for their analysis by reverse-phase high-performance liquid chromatography. Arkivoc 6: 137-146.

Caramori SS, Lima CS and Fernandes KF (2004). Biochemical characterization of selected plant species from Brazilian savannas. Braz. Arch. Biol. Technol. 47: 253-259.

Carvalho PR, Silva DH, Bolzani VS and Furlan M (2005). Antioxidant quinonemethide triterpenes from Salacia campestris. Chem. Biodivers. 2: 367-372.

Cavéchia LA and Proença CEB (2007). Resgate cultural de usos de plantas nativas do Cerrado pela população tradicional da região do atual Distrito Federal. Heringeriana 1: 11-24.

Corsino J, Bolzani VS, Pereira AMS, França SC, et al. (1998). Bioactive sesquiterpene pyridine alkaloids from Maytenus aquifolium. Phytochemistry 48: 137-140.

Corsino J, Carvalho PRF, Kato MJ, Latorre LR, et al. (2000). Biosynthesis of friedelane and quinonemethide triterpenoids is compartimentalized in Maythenus aquifolium and Salacia campestris. Phytochemistry 55: 741-748.

Corsino J, Silva DH, Zanoni MV, da Silva Bolzani V, et al. (2003). Antioxidant flavan-3-ols and flavonol glycosides from Maytenus aquifolium. Phytother. Res. 17: 913-916.

Dagang W, Jikai L and Chunquan C (1992). Angulatueoid G and H, sesquiterpenes from the seeds of Celatrus angulatus. Phytochemistry 31: 4219-4222.

de Oliveira DM, Barreto G, Galeano P, Romero JI, et al. (2011). Paullinia cupana Mart. var. Sorbilis protects human dopaminergic neuroblastoma SH-SY5Y cell line against rotenone-induced cytotoxicity. Hum. Exp. Toxicol. 30: 1382-1391.

Figueiredo JN, Räz B and Sequin U (1998). Novel quinone methides from Salacia kraussii with in vitro antimalarial activity. J. Nat. Prod. 61: 718-723.

Flammang AM, Erexson GL, Mecchi MS and Murli H (2006). Genotoxicity testing of a Salacia oblonga extract. Food Chem. Toxicol. 44: 1868-1874.

Flammang AM, Erexson GL, Mirwald JM and Henwood SM (2007). Toxicological and cytogenetic assessment of a Salacia oblonga extract in a rat subchronic study. Food Chem. Toxicol. 45: 1954-1962. 
González AG, Alvarenga NL, Bazzocchi IL, Ravelo AG, et al. (1998). A new bioactive norquinone-methide triterpene from Maytenus scutioides. Planta Med. 64: 769-771.

Govindaraj Y, Melanaphuru V, Agrahari V, Gupta S, et al. (2009). Genotoxicity studies of mangiferin isolated from Salacia chinensis Linn. Acad. J. Plant Sci. 2: 199-204.

Gullo FP, Sardi JC, Santos VA, Sangalli-Leite F, et al. (2012). Antifungal activity of maytenin and pristimerin. Evid. Based. Complement Alternat. Med. 2012: 340787.

Hayashi M, MacGregor JT, Gatehouse DG, Adler ID, et al. (2000). In vivo rodent erythrocyte micronucleus assay. II. Some aspects of protocol design including repeated treatments, integration with toxicity testing, and automated scoring. Environ. Mol. Mutagen. 35: 234-252.

Hisham A, Kumar GJ, Fujimoto Y and Hara N (1995). Salacione and salacianol, two triterpenes from Salacia beddomei. Phytochemistry 40: 1227-1231.

Jeller AH, Silva DH, Lião LM, Bolzani VS, et al. (2004). Antioxidant phenolic and quinonemethide triterpenes from Cheiloclinium cognatum. Phytochemistry 65: 1977-1982.

Jinbo Z, Mingan W, Wenjun W, Zhiqing J, et al. (2002). Insecticidal sesquiterpene pyridine alkaloids from Euonymus species. Phytochemistry 61: 699-704.

Kilani S, Ben SM, Limem I, Bouhlel I, et al. (2008). In vitro evaluation of antibacterial, antioxidant, cytotoxic and apoptotic activities of the tubers infusion and extracts of Cyperus rotundus. Bioresour. Technol. 99: 9004-9008.

Kleter GA, Groot MJ, Poelman M, Kok EJ, et al. (2009). Timely awareness and prevention of emerging chemical and biochemical risks in foods: proposal for a strategy based on experience with recent cases. Food Chem. Toxicol. 47: 992-1008.

Kraut A and Drnovsek-Olup B (1996). Instillation of mitomycin C after recurrent pterygium surgery. Eur. J. Ophthalmol. 6: 264-267.

Kumar S, Lipman R and Tomasz M (1992). Recognition of specific DNA sequences by mitomycin C for alkylation. Biochemistry 31: 1399-1407.

Lima OG, D'Albuquerque L, Coelho JSB, Maciel GM, et al. (1969). Antimicrobial substances from higher plants. XXX: Antimicrobial and antineoplastic activity of pristimerin isolated from Prionostemma aspera, from the humid bushes of Pernambuco region. Rev. Inst. Antibiot. 9: 17.

Lima OG, Coelho JSB, Maciel GM, Heringer EP, et al. (1972). Substâncias antimicrobianas de plantas superiores: identificação de pristimerina como um componente ativo do "bacupari” do Araguaia, Salacia crassifolia (Mart.) G. Don. (Hippocrateaceae). Rev. Inst. Antibiot. 12: 19-24.

Lombardi JA and Temponi LG (2000). Hipocrateaceae: Flora dos Estados de Goiás e Tocantins. Coleção Rizzo. 1st ed. Universidade Federal de Goiás, Goiânia.

Lu Z, Jin Y, Chen C, Li J, et al. (2010). Pristimerin induces apoptosis in imatinib-resistant chronic myelogenous leukemia cells harboring T315I mutation by blocking NF-kB signaling and depleting Bcr-Abl. Mol. Cancer 9: 112.

Marques RC, de Medeiros SR, Dias CS, Barbosa-Filho JM, et al. (2003). Evaluation of the mutagenic potential of yangambin and of the hydroalcoholic extract of Ocotea duckei by the Ames test. Mutat. Res. 536: 117-120.

Matsuda H, Morikawa T and Yoshikawa M (2002). Antidiabetogenic constituents from several natural medicines. Pure Appl. Chem. 74: 1301-1308.

Miura T, Ichiki H, Hashimoto I, Iwamoto N, et al. (2001). Antidiabetic activity of a xanthone compound, mangiferin. Phytomedicine 8: 85-87.

Morikawa T, Kishi A, Pongpiriyadacha Y, Matsuda H, et al. (2003). Structures of new friedelane-type triterpenes and eudesmane-type sesquiterpene and aldose reductase inhibitors from Salacia chinensis. J. Nat. Prod. 66: 1191-1196.

Muraoka O, Morikawa T, Miyake S, Akaki J, et al. (2010). Quantitative determination of potente $\alpha$-glucosidase inhibitors, salacinol and kotalanol, in Salacia species using liquid chromatography-mass spectrometry. J. Pharm. Biomed. Anal. 52: 770-773.

Nozaki H, Matsuura Y, Hirono S, Kasai R, et al. (1990). Antitumor agents, 116. Cytotoxic triterpenes from Maytenus diversifolia. J. Nat. Prod. 53: 1039-1041.

Santana CF, Asfora JJ and Cotias CT (1971). Primeiras observações sobre o emprego da maitenina em pacientes cancerosos. Rev. Inst. Antibiot. 11: 37-49.

Silva Júnior MC (2005). 100 Árvores do Cerrado: Guia de Campo. 1st ed. Rede de Sementes do Cerrado, Brasília, DF.

Somwong P, Suttisri R and Buakeaw A (2011). A new 1,3-diketofriedelane triterpene from Salacia verrucosa. Fitoterapia 82: 1047-1051.

von Ledebur M and Schmid W (1973). The micronucleus test. Methodological aspects. Mutat. Res. 19: 109-117.

Yadav VR, Prasad S, Sung B, Kannappan R, et al. (2010). Targeting inflammatory pathways by triterpenoids for prevention and treatment of cancer. Toxins 2: 2428-2466. 